\title{
REMOTE SENSING OF THE ROSS ICE STREAMS AND ADJACENT ROSS ICE SHELF, ANTARCTICA
}

\author{
by \\ C.R. Bentley, S. Shabtaie, D.D. Blankenship, S.T. Rooney, D.G. Schultz, S. Anandakrishnan and R.B.
Alley \\ (Geophysical and Polar Research Center, University of Wisconsin-Madison, 1215 W. Dayton Street, \\ Madison, WI 53706, U.S.A.)
}

\begin{abstract}
In the first few seasons of the Antarctic Siple Coast project, the University of Wisconsin has concentrated on radar and seismic studies. Highlights of the results to date include the delineation of ice streams A, B, and C and the ridges in between, determination of the surface elevations over the area, discovery of a much more advanced grounding line than previously recognized and recognition of a broad, flat, barely grounded "ice plain" just inside the grounding line. Complex zones between and adjoining some of the ice streams, characterized by an interspersal of undisturbed ice and crevassed patches, give the impression of being transformed from sheet flow into stream flow in a process of ice stream expansion. An indicated negative mass balance for ice stream B could be the result of this "activation" process. Ice stream C, currently stagnant, exhibits terraces and reversals of surface slope, associated with zones of strong, steady basal radar reflections. These features suggest that subglacial water has been trapped by reversals in the hydrauilic pressure gradient.
\end{abstract}

Low seismic P-wave and S-wave velocities in a metersthick layer immediately below the ice strongly indicate a saturated sediment of such high porosity $(\sim 40 \%)$ and low effective (differential) pressure $(\sim 50 \mathrm{kPa}$, or $0.5 \%$ of the glaciostatic pressure) that it must be too weak not to be deforming. We presume this deforming layer to be a dilated till. Its base exhibits ridges and troughs parallel to the flow direction that resemble glacial megaflutes. We believe that at our site on the upper part of ice stream B the ice stream moves principally by deforming its bed. Analysis of seismographic recordings of micro-earthquakes that occur at the glacier bed shows that the micro-earthquakes are both small in energy and infrequent. This implies that virtually none of the energy of ice stream motion is dissipated by brittle fracture at the bed. If our models are correct, the subglacial deforming till becomes increasingly soft down-glacier, and/or the ice becomes decoupled from the till by intervening water, until on the "ice plain" basal drag is less important than longitudinal stresses in the dynamic balance. Our models also imply that the "ice plains" rest on "till deltas" that have been formed by the deposition of till carried along beneath the ice streams, and that the till deltas, and the grounding lines that bound them, are currently advancing in front of the active ice streams.

\section{INTRODUCTION}

During the past several years the Geophysical and Polar Research Center has been conducting a program of geophysical investigations of the Siple and Gould Coast regions of the West Antarctic ice sheet, and of the adjacent parts of the Ross Ice Shelf. Our research work has concentrated on radar and seismic studies of the glacier bed, but has also yielded a substantial amount of information concerning the glacier surface and internal characteristics. In this paper we give a review of the major findings of this program to date. This is not yet a comprehensive report on the results of this work, since extensive analysis remains to be done on data already in hand; furthermore the field program will be continuing in the future. Elsewhere in this volume we report on two of the specific improvements in our remotesensing capabilities that have been put to use effectively in recent seasons (Blankenship and others 1987; Schultz and others 1987).

The major focus of the research project being carried out by the University of Wisconsin in conjunction with The Ohio State University, NASA, and the University of Chicago is the "Ross ice streams", which are the dynamically dominant feature of the part of the West Antarctic inland ice sheet that feeds into the Ross Ice Shelf (Robin and others 1970[a]; Rose 1979). The work done to date has concentrated on ice stream B and Crary Ice Rise, but with extensive reconnaissance work over ice streams A and C, and ridges $\mathrm{AB}$ and $\mathrm{BC}$ (Fig.1).

\section{MAPPING OF ICE STREAMS}

A very important first result of the airborne radar program has been the mapping of ice streams $\mathrm{A}, \mathrm{B}$, and $\mathrm{C}$ and their marginal shear bands that is more detailed than the previous mapping by Rose (1979). As was shown previously by Robin and others (1970[a]) and Rose (1979), radargrams over the ice streams show strong scattered returns from inhomogeneities, especially crevasses, at and near the air-ice interface, producing a prolongation of the surface echo called "clutter". Clutter results from buried as well as surface crevasses, so it is an effective diagnostic feature of ice streams whose surfaces are characterized by crevasses, most of which are buried (Fig.2). The clutter from the marginal shear zones is of ten longer lasting than that from the other parts of the ice stream, presumably because the large open crevasses along the margins are particularly effective scatterers of energy. Using both the scatter from the bodies of the ice streams and the prolonged returns from their margins, which can be traced from cross-section to cross-section, Shabtaie and Bentley (1986; in press) produced the map of the ice streams that is shown in Fig.3.

It also has been possible to delineate the grounding lines that mark the boundary between the inland ice and the ice shelf (Shabtaie and Bentley 1986; in press). In places where the inland ice is moving relatively slowly, the grounding line is readily apparent from the surface elevation profile, and in fact can even be seen visually from the surface. However, that is not true down-stream of the active ice streams. The radar data have been used in two ways to delineate the grounding lines in those regions. In the first place, ice thicknesses can be compared with precise surface elevations obtained by satellite measurements at ground stations to determine whether the surface of the ice shelf is at or above buoyancy. Secondly, characteristics of the radar signals can be used directly. Two are particularly useful. (1) Hyperbolic returns occur from near the base of the ice; we interpret these as being due to bottom crevasses. 
$2^{\circ}$

i̊

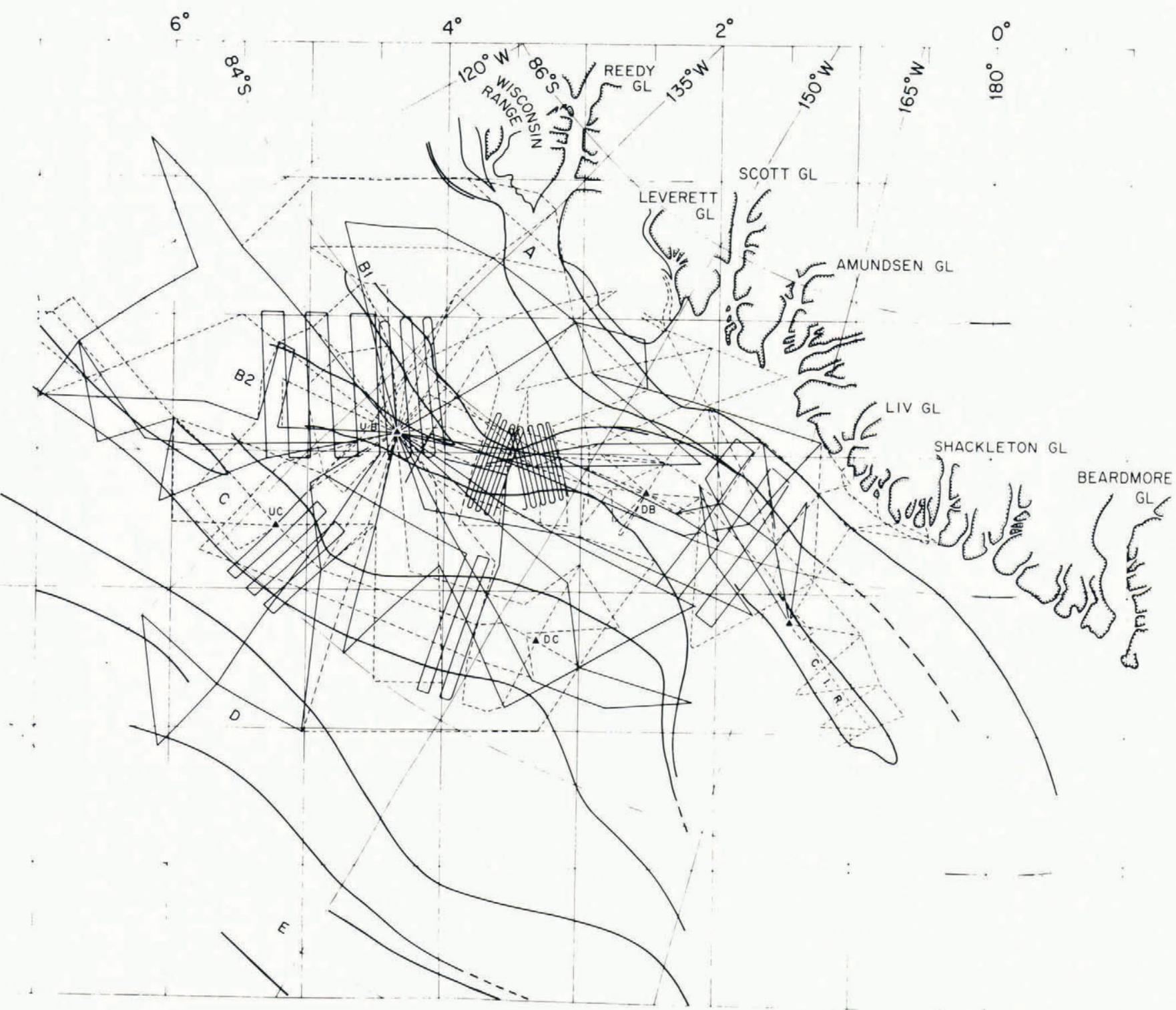

@o

Fig.1. Map of Siple Coast region showing radar flight lines. Solid lines are 1985-86 flights using digital recording; dashed lines are 1984-85 flights with analog recording. Ice streams are marked by the letters A-E; C.I.R. is Crary Ice Rise. Base camps are denoted by triangles. In the rectangular grid coordinate system shown here and on other maps, the origin is at the South Pole and grid north is toward Greenwich. (Delineation of ice streams is not exact - Fig.3 should be used for greater accuracy.)

We have not observed bottom crevasses anywhere on the grounded ice, so we assume that the presence of bottom crevasses on a flight line means that the grounding line must be upstream. (2) The bottom echo from the grounded ice usually shows a fading pattern (i.e. rapid changes in echo strength) that is typical of inland ice sheets, whereas the bottom echo from the ice shelf is relatively smooth and strong. From this combination of data, Shabtaie and Bentley (in press) drew the grounding line in the position shown on the map in Fig.4, where it is contrasted with the position formerly mapped by Rose (1979), who did not have the benefit of precise satellite measurements of surface elevations.

The heads of the ice streams have not yet been mapped clearly. In fact, this may be difficult to do. Ice stream $A$ is fed by Reedy Glacier and by the Shimizu/Horlick ice stream, both of which have their origins on the East Antarctic side of the Transantarctic Mountains. Ice streams B and C, on the other hand, clearly start within the West Antarctic inland ice, but with a complex boundary zone, especially in the case of ice stream B (Fig.3). Just what physiographic features (in addition to crevasses) or analytical characteristics of the ice mark the beginning of the ice streams, if indeed any clear demarka- tion exists, remains to be seen from further analysis of the data on hand and concentrated study that is planned for the
future.

The complexity of "ridge- B1/B2" between ice streams B1 and B2 (Figs. 3 and 5) is particularly striking. Within this "ridge" several "islands" and "peninsulas" of clutter-free ice are separated by disturbed ice zones. We believe that the many irregular and discordant zones of crevasses are indicative of a region in transition; more specifically we believe that sections of the surrounding ice sheet are being transformed into stream flow, so that ice stream B is actually growing. We will return to this point later.

\section{SURFACE ELEVATIONS}

Another important product of airborne radar is the determination of the surface elevations of the ice sheet. Our radar-sounding flights are carried out as nearly as possible at a constant pressure elevation as determined by the barometric altimeter in the aircraft. Ice surface elevations relative to the aircraft are determined from the surface echo on the radargrams. As part of the Siple Coast project, a number of surface stations at which the elevation was measured by satellite observations were established. 


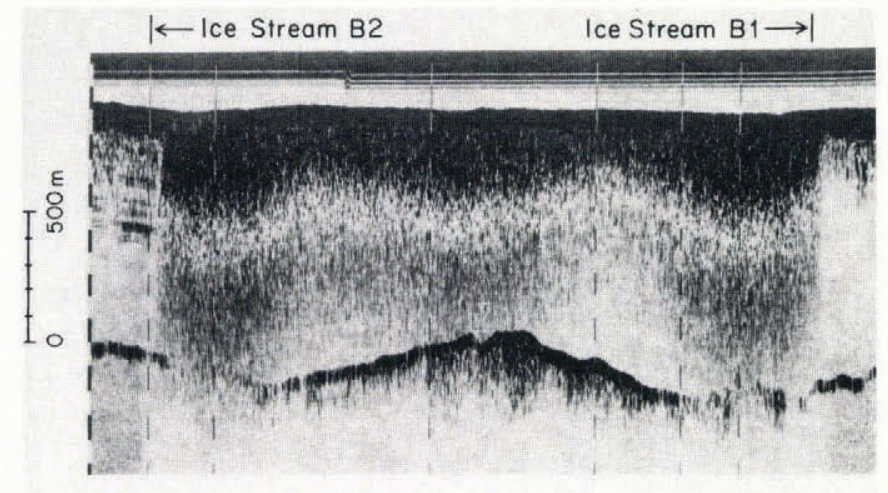

$10 \mathrm{~km}$

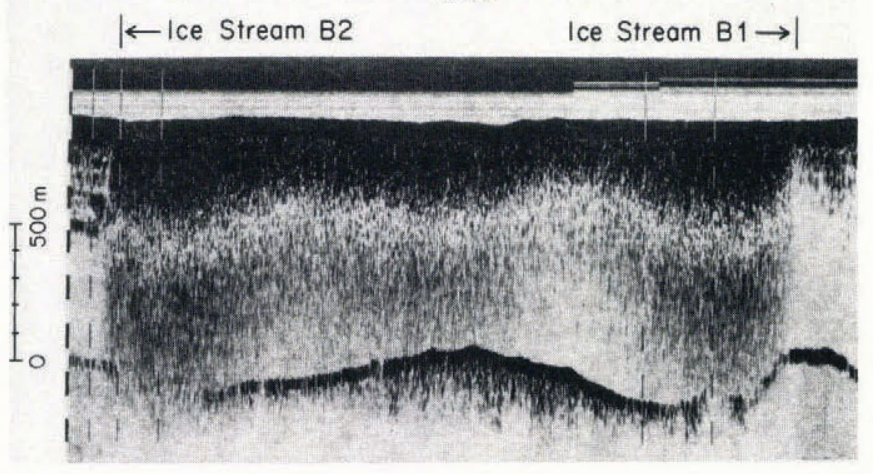

Fig.2. Radargrams showing two cross-sections of ice stream $\mathrm{B}$ around $3.3^{\circ} \mathrm{W}$. Grid north is on the right. The lower section is about $7 \mathrm{~km}$ grid east (down-glacier) from the upper. Surface and bottom echoes and clutter, stronger near the ice-stream boundaries, are seen in each radargram. The boundary between ice streams B1 and B2 is not shown as its position is not certain.

Radar-sounding flights were designed to pass over as many of these ground control stations as possible. This provided excellent control on the absolute elevation of the surface beneath the flight lines. Furthermore, the flight lines crossed each other in many places, so that intertrack ties could be made. Analysis of the results has indicated that surface elevations obtained by radar are good to between \pm 10 and $\pm 25 \mathrm{~m}$, depending on the distance from the nearest tie point (Shabtaie and Bentley in press). Consequently, our new map (Fig.5) should be more accurate as well as more detailed than the regional map of Drewry (1983), who cited an error of $30-50 \mathrm{~m}$.

\section{ICE STREAM B}

We now turn our attention to some of the specific characteristics of ice stream $B$ that have been revealed by remote sensing. Ice stream $B$ has two branches, called B1 and B2, which merge around grid $4^{\circ} \mathrm{W}$; the boundary between the two persists downstream as a suture zone as far as grid $2^{\circ} \mathrm{W}$ (Fig.3). Even well below the junction at $3.3^{\circ} \mathrm{W}$ the bed continues to be marked by two distinct troughs (Fig.2). The trough beneath ice stream B1 is somewhat the more pronounced of the two, but neither is very deep compared to most ice streams (Bentley in press) - the total subglacial relief on the section of Fig.2 is less than $300 \mathrm{~m}$. Farther upglacier, adjoining "ridge B1/B2", the trough beneath ice stream Bl is $300 \mathrm{~m}$ deeper than in Fig.2; downglacier it continues to shoal until it is $100 \mathrm{~m}$ less deep than the trough beneath ice stream B2, which has a less varying depth (Shabtaie and others in press[b]).

Seismic reflection studies conducted at Upstream B Camp (UB) revealed the existence of two reflectors near the base of the ice (Blankenship and others 1986; in press), Both compressional wave ( $\mathrm{P}$-wave) and shear wave ( $\mathrm{S}$-wave) reflections were recorded, each from both the upper and lower reflector. These reflections were seen not only on vertical but also on "wide angle" (oblique) reflection profiles, from which the $\mathrm{P}$-wave and $\mathrm{S}$-wave speeds in the layer were determined. The low $\mathrm{P}$-wave speed, near to that in water, and the extremely low S-wave speed, less than $10 \%$ that for the $\mathrm{P}$-waves, together mean that the layer must have a relatively high porosity (about $40 \%$ ) and be saturated with water at high pressure $-99 \frac{1}{2} \%$ of the glaciostatic overburden pressure must be supported by fluid pressure in the pores (Blankenship and others in press). The combination of high porosity and low effective pressure between sedimentary particles implies that the layer, which averages about $6 \mathrm{~m}$ thick along the sections that have been measured (Rooney and others in press), must be very weak. From this we have concluded that at least at Upstream B the ice stream moves primarily by deforming its bed rather than by sliding over it (Alley and others 1986; in press [a]).

The seismic reflections further showed that along the direction of ice movement the subglacial reflecting horizon is parallel to the bottom of the ice, but that transverse to the ice movement there is much less continuity in the subglacial reflectors (Rooney and others in press). The picture that emerges is one of ridges and valleys in the basal surface of the subglacial layer trending parallel to the axis of the ice stream. The alignment of these features along the direction of movement suggests that they are formed by erosion. The fact that there is no image of the ridges and troughs in the glacial-subglacial interface is further support for the model of a deforming bed that we have proposed. The largest of these flutes or grooves are over $10 \mathrm{~m}$ deep and more than a kilometer across, although more generally they are about $200-300 \mathrm{~m}$ across (Fig.6). The general appearance of these flutes is similar to glacial flutes observed on deglaciated terrain of the Laurentide ice sheet, such as in northern and central Alberta (Gravenor and Meneley 1958).

Other interesting features that show up on the seismic cross-sections are linear diffractors parallel to ice movement that suggest a chain of boulders entrained in the top of the till (other interpretations are also possible), isolated ridges parallel to ice flow where the till becomes very thin or pinches out entirely, and dipping reflectors beneath the deforming till that suggest an angular unconformity at the base of the deforming till (Rooney and others in press). Preliminary examination of other field records indicates that the till is probably continuous along a profile $12 \mathrm{~km}$ long parallel to the axis of the ice stream.

If our model of a basal deforming till is correct for the whole ice stream, it follows that the till is being transported downstream and deposited where the ice loses its ability to transport it (Alley and others 1986). A very flat region of barely grounded ice, which we propose to call an "ice plain", characterizes the downstream ends of ice streams $A$ and B (Figs 4 and 5). We believe the bed beneath the "ice plain" to have been formed by the deposition, below formerly floating ice, of till carried along beneath the ice streams. The low to non-existent slope of the surface (first profiled, but not recognized as distinct from the ice shelf, by Robin and others (1970[b])), combined with the fast measured ice velocities in the "ice plain", suggest that the movement is primarily ice-shelf-like (dominated by longitudinal stresses) rather than ice-stream-like (dominated by basal shear stresses). It follows further that the transport of till will result in a growing "till delta" beneath the "ice plain", and an advancing grounding line. A similar process of transport was proposed long ago for the whole Ross Ice Shelf by Poulter (1950), although he believed tidal lifting would aid the forward motion of the ice. In fact, the "ice plain" lies several tens of meters above hydrostatic balance so tidal flotation does not occur. Strand cracks have been found at the "ice plain" grounding line near Crary Ice Rise (Bindschadler and others in press).

Supporting evidence for the existence of a soft bed directly beneath the "ice plain" comes from an examination of the seismic reflection records recorded as part of the Ross Ice Shelf Geophysical and Glaciological Survey 


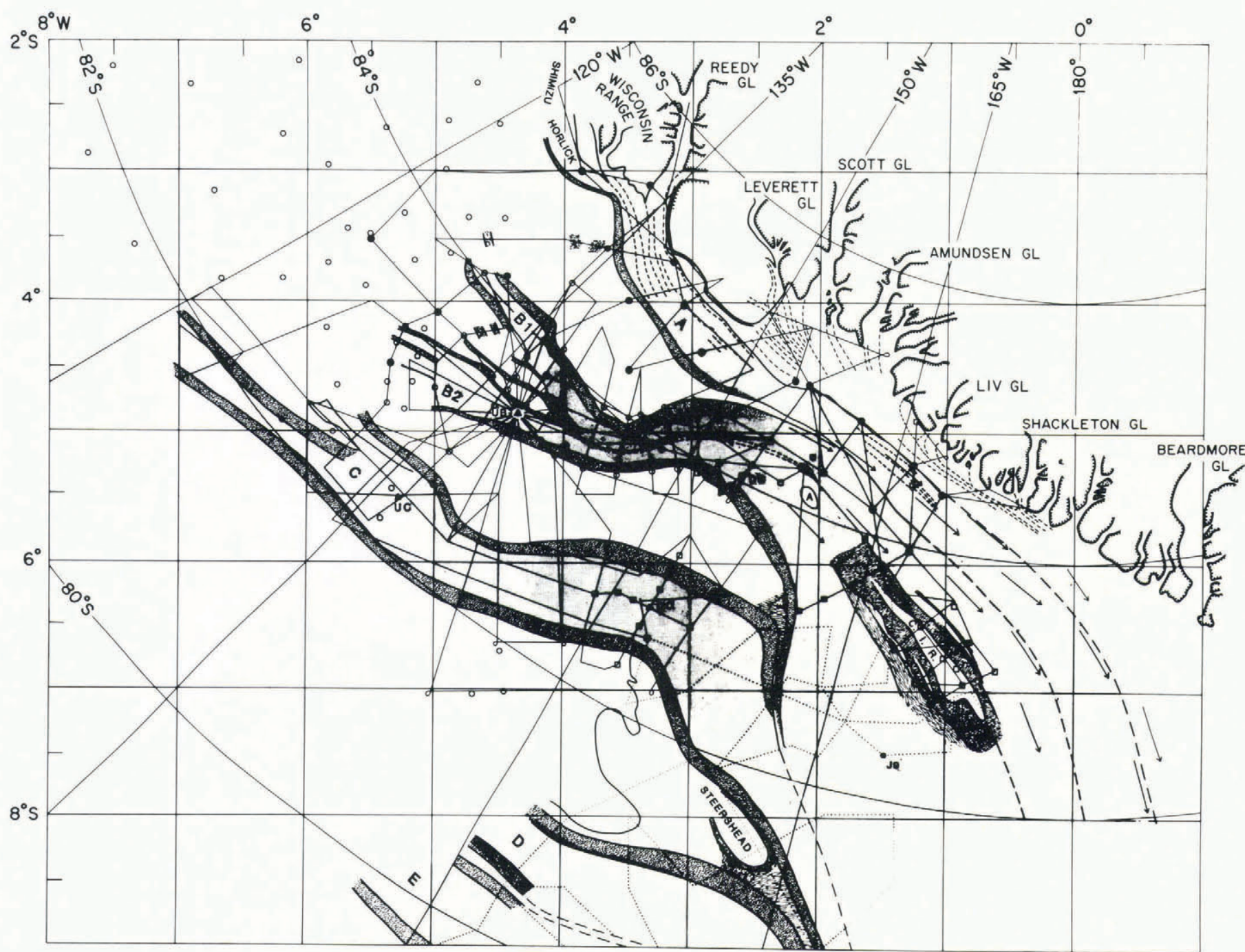

Fig.3. Map of Siple Coast region showing the boundaries of the ice streams and ice rises (a, A, and C.I.R.). Thin solid lines are 1984-85 flight lines; dotted lines are flights from the mid 1970s ("RIGGS"). 1985-86 flights are not shown. Solid circles, open circles, and open squares denote surface stations. From Shabtaie and Bentley (in press).

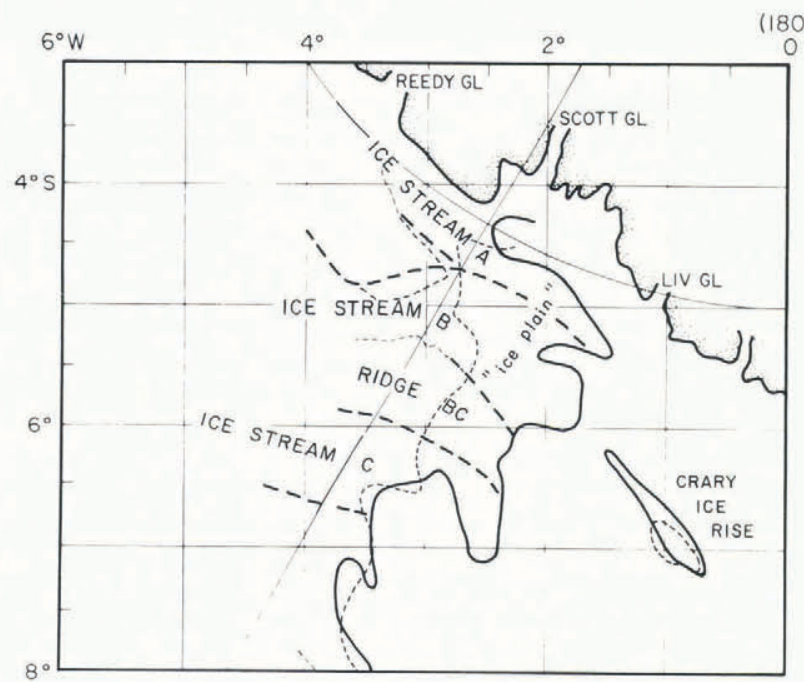

Fig.4. Simplified map of the Siple Coast showing new (solid) and old (light dashed) boundary lines and the region which we proposed to designate an "ice plain". The old boundary lines are from Rose (1979); the new from Shabtaie and Bentley (1986). Heavy dashed lines mark the lateral boundaries of the ice streams.
(RIGGS) in 1973-74 (Robertson unpublished; Robertson and Bentley in press). The best seismogram from each of six stations is reproduced in Fig.7. Stations E5, E6, and E7 are on the "ice plain". Stations E8 and F9 lie on the floating ice shelf over deep water down-stream from ice stream A. The reflection records at E5, E6, and E7 (Fig.7a) show poor or very poor single reflections that were originally interpreted by Robertson (unpublished) as being from the sea floor. However, the characteristics of the seismograms from E8 and F9 (Fig.7b), where both the ice-bottom and sea-bottom reflections are unequivocal, are clearly very different. We believe now that the reflections at E5, E6 and E7 are from within the sedimentary column, and that the ice/sediment reflection is not seen.

There is reason to believe that a reflection from the ice/sediment boundary might not be observable. If we assume that the sediments are the same as those beneath station $\mathrm{UpB}$, except that they are no longer dilated, then we estimate the P-wave velocity at $1700 \mathrm{~m} \mathrm{~s}^{-1}$ and the density at $2.0 \mathrm{Mg} \mathrm{m}^{-3}$; the acoustic impedance would then be $3400 \mathrm{Mg} \mathrm{m}^{-2} \mathrm{~s}^{-1}$. For the base of the ice shelf, with a density of $0.91 \mathrm{Mg} \mathrm{m}^{-3}$ and a wave velocity of $3700 \mathrm{~m} \mathrm{~s}^{-1}$ (Robertson unpublished), the acoustic impedance is also $3400 \mathrm{Mg} \mathrm{m}^{-2} \mathrm{~s}^{-1}$. Even if the presumed till were dilated, its acoustic imepdance, $\sim 3000 \mathrm{Mg} \mathrm{m}^{-2} \mathrm{~s}^{-1}$, would not be largely different from that of the ice. Thus, though conditions in the sea floor may vary considerably from place to place, 


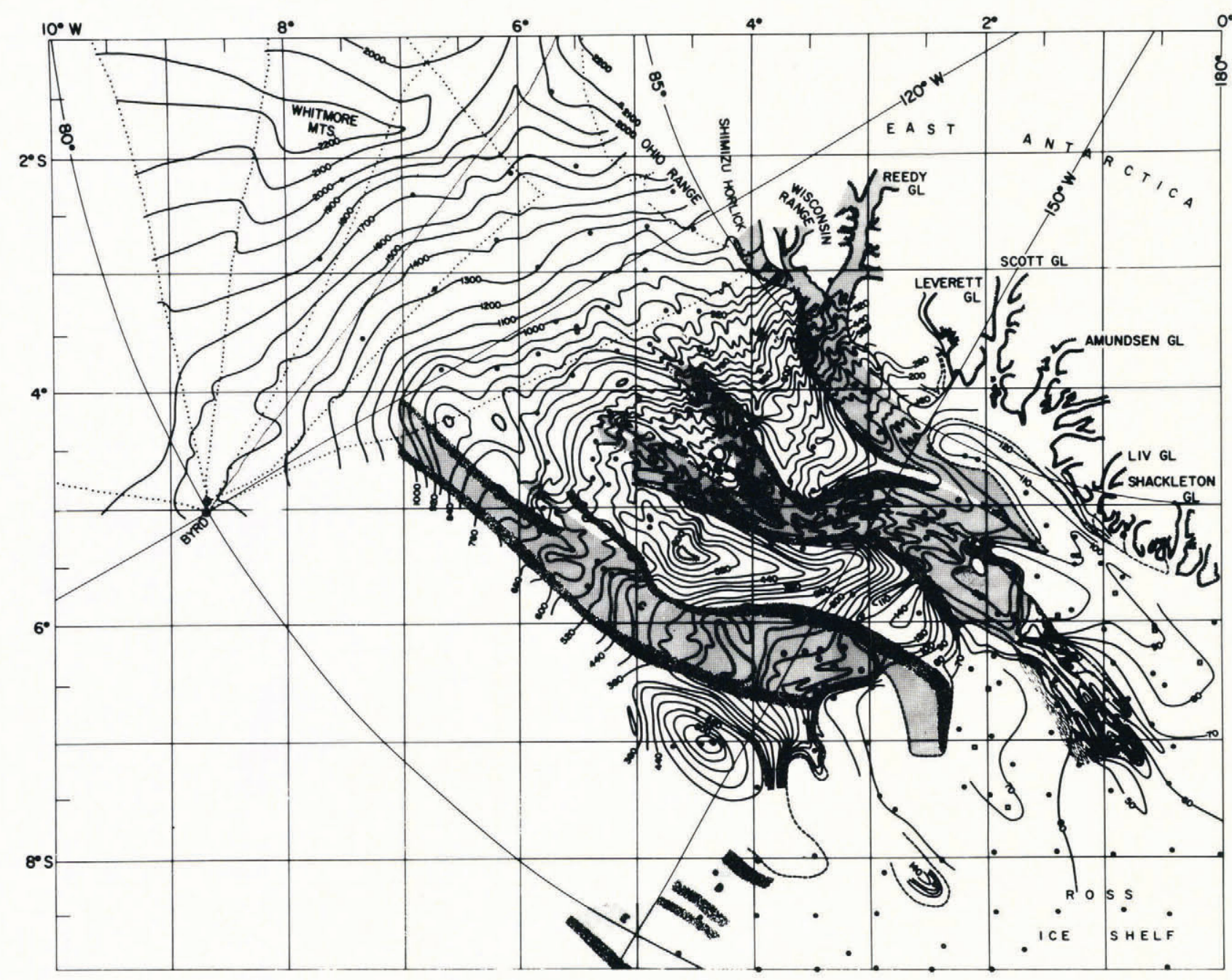

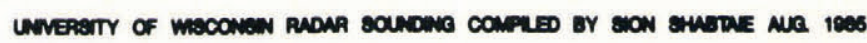

Fig.5. Surface-elevation map of the Siple Coast region. Contour interval is $10 \mathrm{~m}$ up to $120 \mathrm{~m}, 20 \mathrm{~m}$ from $120 \mathrm{~m}$ to $200 \mathrm{~m}, 40 \mathrm{~m}$ from $200 \mathrm{~m}$ to $1000 \mathrm{~m}$, and $100 \mathrm{~m}$ for higher elevations. The short-dashed lines denote the grounding line, long-dashed lines delineate some ice-stream boundaries, and dotted lines are oversnow traverse tracks. From Shabtaie and others (in press).

the acoustic impedance contrast could certainly be very small, so that the absence of a bottom reflection would not be surprising.

Also shown in Fig.7b is a reflection record from station F7 on the edge of the "ice plain" - this, the only case of a strong reflection on the "plain", suggests that there is a hard bottom at this spot (grid position $5.6^{\circ} \mathrm{S}, 1.8^{\circ} \mathrm{W}-$ see Fig.5).

Remote sensing also gives information about the internal characteristics of the ice. The same wide-angle seismic reflection profiles that yielded the seismic velocities in the subglacial layer also yield velocities in the ice itself. Wide-angle reflection measurements elsewhere have generally revealed that a substantial fraction of the ice sheet in most places is anisotropic (Bentley 1971; Blankenship unpublished). In contrast, the P-wave measurements at $\mathrm{UpB}$ show little or no anisotropy (Blankenship and others in press). On the other hand, the S-wave measurements, which are more sensitive to anisotropy, do indicate a difference between the speeds of shear waves with different polarizations.

Analysis of both S-wave reflections and waves that have been converted from $P$ to $S$ upon reflection from the bottom of the ice on a wide-angle profile along the flow direction indicates that transversely polarized $\mathrm{S}$ waves (SH waves) travel $1 \%$ or $2 \%$ faster than waves polarized in the plane of the profile. Furthermore, the very fact that $P$ waves are converted into $\mathrm{SH}$ waves upon reflection is direct evidence for the existence of some anisotropy at the base of the ice. Blankenship and others (1987) also observe a $2 \%$ difference in wave velocity for shear waves of different polarization generated by micro-earthquakes at the base of the ice stream (Fig.8).

Nevertheless, from the P-wave evidence, it appears that the ice in the ice stream is more nearly isotropic than sheet-flow ice elsewhere in West Antarctica and at Dome C. If the anisotropic structure at Byrd Station (Gow 1970; Bentley 1972; Kohnen and Gow 1979), in the catchment area for ice stream D, is typical also of ice in the catchment area for ice stream B, then a pronounced fabric must be destroyed somewhere along the flow path. Perhaps this occurs when the ice goes through a region of strong extensional stresses at the head of the ice stream where the ice is accelerated to the ice-stream speeds.

Geophysical remote sensing also provides us with information about the dynamics of ice stream B. Part of this information comes from the new passive seismic recording system that is described by Blankenship and others (1987). Twenty-six micro-earthquakes were detected and recorded during 85 hours of seismic monitoring. About half of the events were associated with crevassing near the surface of the ice stream, presumably near the margins. The most interesting phenomenon, however, was a group of 9 small micro-earthquakes occurring only minutes apart. Preliminary analysis of the location and focal 

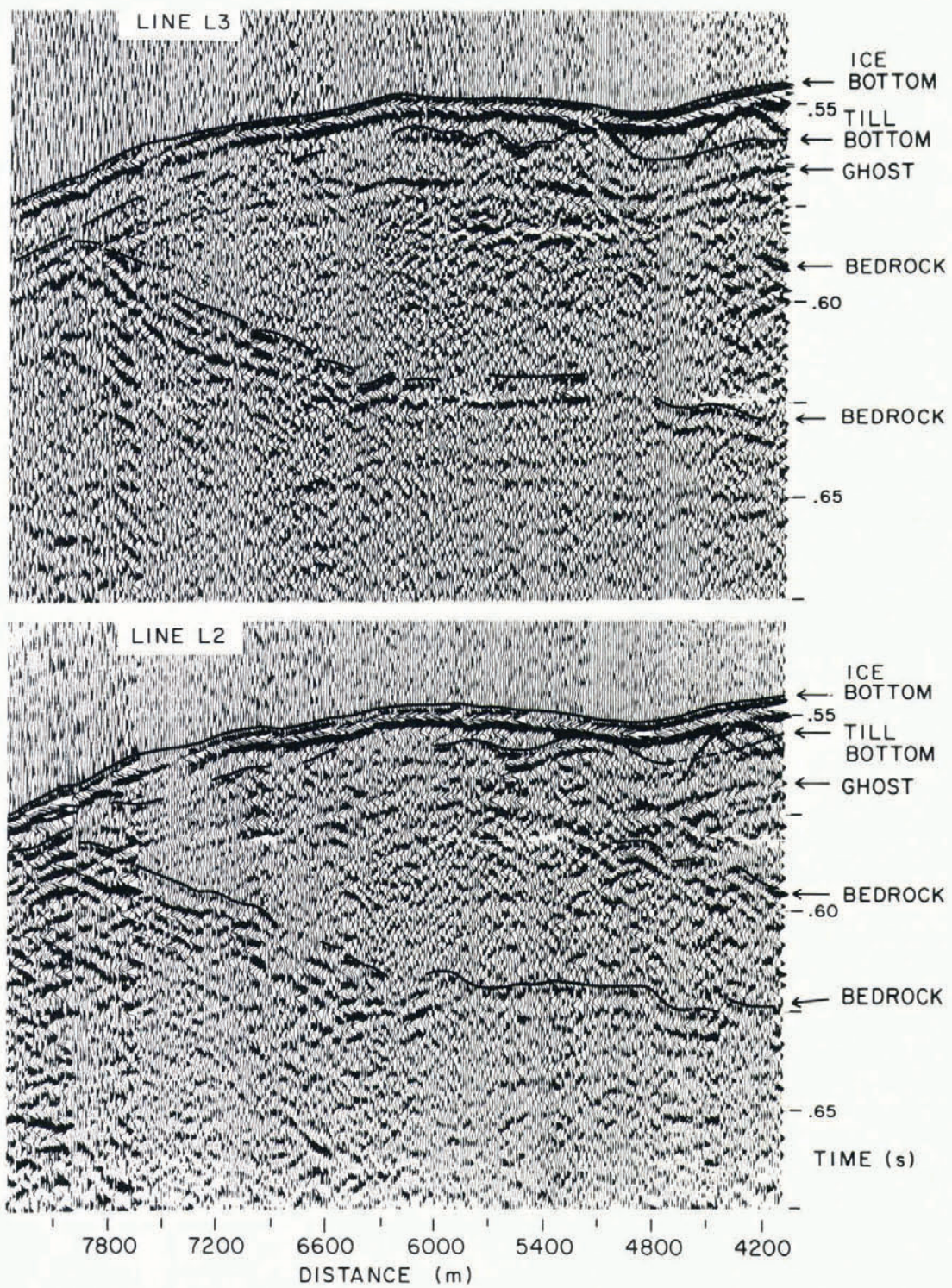

Fig.6. Two parallel $4 \mathrm{~km}$ long seismic reflection sections transverse to the ice-stream axis at camp UB. Ice-bottom and (mobile) till-bottom reflections are labeled; later marked events are reflections from sedimentary rock layers which appear truncated by the mobile till-bottom reflection. From Rooney and others (in press).

mechanism of these events (Blankenship and others 1987) shows that they were associated with slip on low-angle thrust planes at or near the bottom of the ice stream. The paucity of micro-earthquakes arising from the bottom of the ice stream leads Blankenship and others (1987) to conclude that virtually none of the energy of ice stream motion is dissipated by brittle fracture at the bed.

The complex "ridge B1/B2" zone between ice streams B1 and B2, which appears to be breaking up as the ice streams grow, has already been described. We find support for the hypothesis that ice stream B is growing headward from a consideration of its mass balance. The flux out of ice stream B into the Ross Ice Shelf is perhaps as much as twice as large as the input into the entire drainage basin of the ice stream - the apparent imbalance is $10-20 \mathrm{~km}^{3} \mathrm{a}^{-1}$ (Shabtaie and Bentley in press). Our co-operative work with Whillans (Shabtaie and others in press[a]) suggests that about half of that can be attributed to the zone in apparent transition, which has an area of about $10^{4} \mathrm{~km}^{2}$. That would imply a mean surface lowering of one or two meters per year. Surface lowerings several times this have been measured locally by Whillans and others (in press), as one might expect if the ice at a particular location is being transformed from sheet flow to ice stream flow.

The dynamics of the ice stream are bound to be fundamently affected if the deforming till is extensive underneath the ice stream. Alley and others (in press[b]) have developed a simple one-dimensional model for icestream flow on deforming till. The model assumes continuity of ice and till and a linear-viscous till rheology. The steady-state solution requires that the viscosity decrease downstream; we believe this probably results from a combination of decreasing effective pressure in the till and partial decoupling between the ice and the till. Numerical experiments with fixed ice thicknesses at the ends show that a perturbation at one end causes a wave of adjustment to travel the length of the ice stream in about 50 years, with a new steady-state attained in about 200 years. This rapid adjustment suggests that any non-steady effects observed in the ice stream probably represent continuing changes in the ice sheet above the ice stream or in the ice shelf downstream. As we discussed above, we believe that in ice stream $B$ the deviation from steady-state reflects on-going changes at the head of the ice stream.

\section{ICE STREAM C}

Ice stream $\mathrm{C}$ is of particular interest because it has ceased its rapid motion. It now moves less than $10 \mathrm{~m} / \mathrm{yr}$ both at its grounding line (Thomas and others 1984; Bindschadler and others in press) and at Upstream C camp (UC in Figs 1 and 3) (I.M. Whillans personal communication, 1985). Yet it clearly has been an active ice stream in the past - despite the absence of surface crevasses 


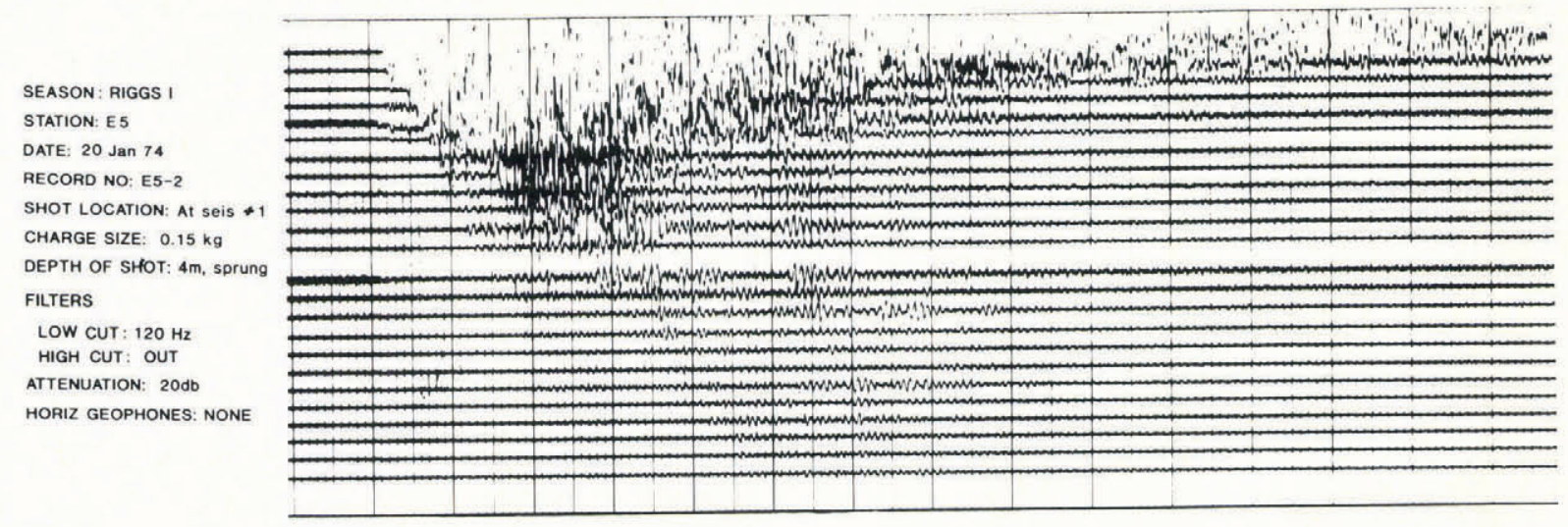

SEASON : RIGGS I

STATION: E6

DATE: 19 Jan 74

RECORD NO: E6-3

SHOT LOCATION: At seis $\$ 1$ CHARGE SIZE: $0.15 \mathrm{~kg}$ DEPTH OF SHOT: $4 \mathrm{~m}$, sprun

FILTERS

LOW CUT: $120 \mathrm{~Hz}$ HIGH CUT: OUT

ATTENUATION: 20db

HORIZ GEOPHONES: NONE
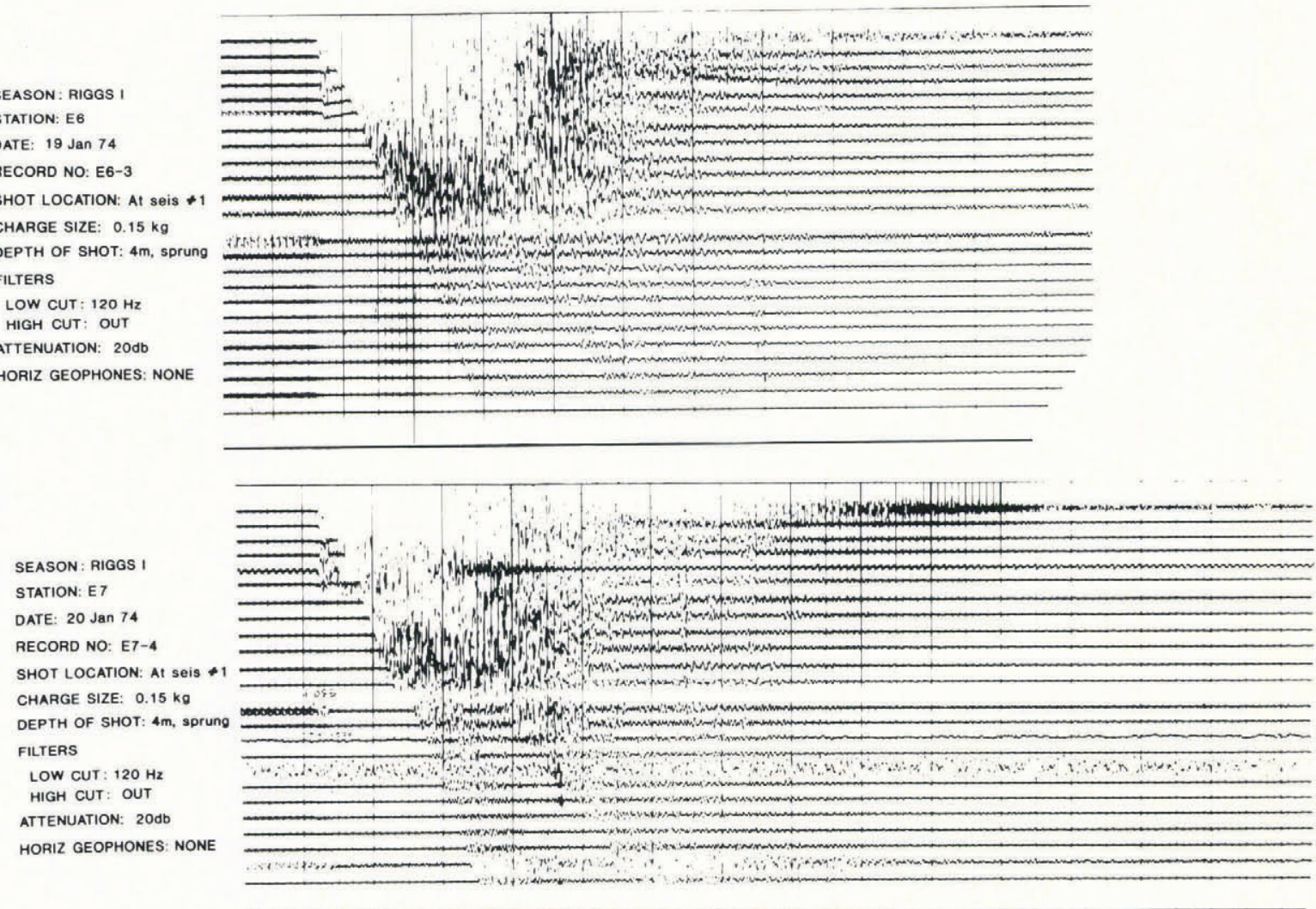

Fig.7a. Seismic reflection records from the grid northwest corner of the Ross Ice Shelf and neighboring "ice plain". Records from stations E5, E6, and E7, all on the "ice plain"; note poor quality of the reflections.

(Robin and others 1970[a]) the radar-sounding records across it show the clutter echoes in the body of the ice stream and the marginal shear zones that are diagnostic of other ice streams (Rose 1979; Shabtaie and Bentley in press). Rose (1979) pointed out that the depth of burial of crevasses could give the date ice stream $C$ was last active, but the resolution of his system allowed him only to say that that date was within the last 1000 years. A sounding program we carried out on the surface at UpC using a monopulse radar revealed numerous hyperbolae generated from the tops of crevasses $30-40 \mathrm{~m}$ below the surface. From measurements of snow accumulation rate and density, Shabtaie and Bentley (in press) estimate that the crevasses ceased to form about 250 years ago. As the crevasses might have been buried to some extent while ice stream C was still active, 250 years would then represent the upper limit to the time that has passed since ice stream $C$ stagnated.

Since ice stream C is barely moving, its mass balance is strongly positive. Even if one assumes that the entire catchment area that once fed ice stream $\mathrm{C}$ is now diverted to ice streams B and D, the mass that falls on the surface of ice stream $C$ itself is still eight times as large as the output flux (Shabtaie and Bentley in press). (If one includes the nominal catchment area, the ratio is almost $40: 1$.) Clearly, then, ice stream $\mathrm{C}$ must be growing in elevation, and it seems likely that some time in the future it will become reactivated.

The map of surface elevations (Fig.5) (Shabtaie and others in press[b]) shows several minima in the surface of ice stream C. Flat spots were observed years ago by Robin and others (1970[b]), in an area that we now know to be on the sheet-flow ice grid southwest of ice stream C (Siple ice dome). They also noted that strong radar echoes were associated with these spots, and attributed both the flat surface and the strong echoes to "pseudo ice shelves" floating on trapped subglacial water without a hydrostatic connection to the sea. Detailed work by Shabtaie and others (in press[b]) has indicated that strongly reflecting areas are also found beneath ice stream $C$, and that in some places the hydraulic pressure gradient at the bed is negative, i.e. such as to force water locally up-stream. Although a correlation between strong reflections and negative hydraulic pressure gradients has not been established, it is nevertheless interesting to speculate whether the Robin and Weertman (1973) instability mechanism, which depends upon reversals in the hydraulic pressure gradient, may become 
SEASON : RIGGS I

STATION: E8

DATE: 19 Jan 74

RECORD NO: E8-3

SHOT LOCATION: At seis +1

CHARGE SIZE: $0.15 \mathrm{~kg}$

DEPTH OF SHOT: $4 \mathrm{~m}$, sprung

FILTERS

LOW CUT: $210 \mathrm{~Hz}$

HIGH CUT: OUT

ATTENUATION: 20dB

HORIZ GEOPHONES: NONE

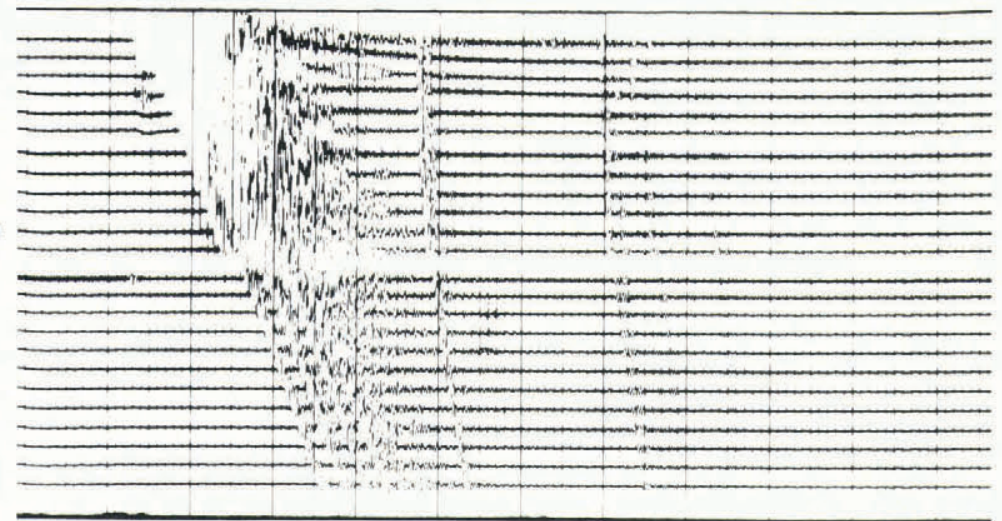

STATION: F9

DATE: 18 Jan 74

RECORD NO: F9-1

SHOT LOCATION: At SEIS *

CHARGE SIZE: $0.15 \mathrm{~kg}$

DEPTH OF SHOT: $4 \mathrm{~m}$, sprung

FILTERS

LOW CUT: $210 \mathrm{~Hz}$

HIGH CUT: OUT

ATTENUATION: 20db

HORIZ GEOPHONES: NONE

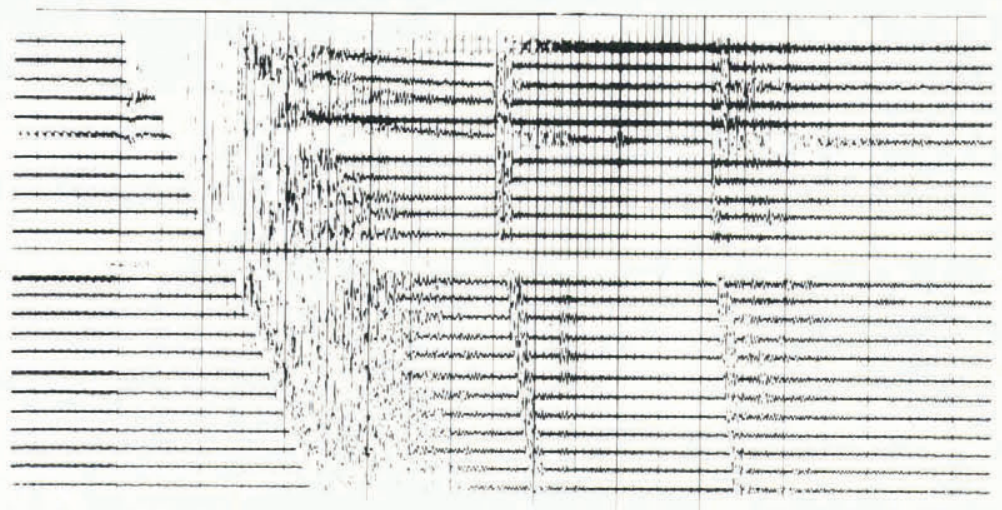

SEASON : RIGGS I

STATION: F7

DATE: 18 Jan 74

RECORO NO: FT-3

SHOT LOCATION: At seis +

CHARGE SIZE: $0.15 \mathrm{~kg}$

DEPTH OF SHOT: $4 \mathrm{~m}$, sprung

FILTERS

LOW CUT: $210 \mathrm{~Hz}$

HIGH CUT: OUT

ATTENUATION: 20db

HORIZ GEOPHONES: NONE

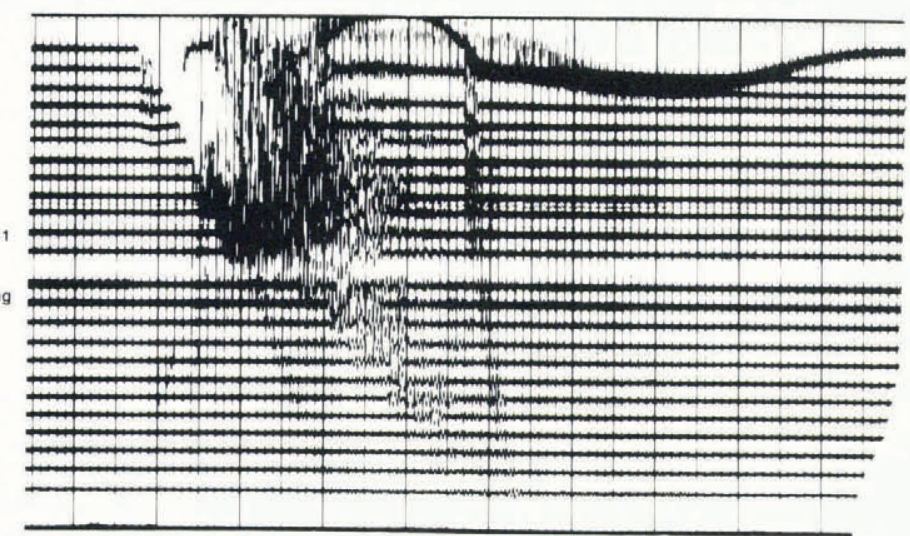

Fig.7b. Records from stations E8 and F9 on the floating ice shelf; note the excellent reflection quality.

Also shown is a record from station F7, on the edge of the "ice plain".

operative beneath ice stream $\mathrm{C}$ and lead to its eventual re-activation, rather as suggested by Hughes (1975).

\section{OTHER ICE STREAMS AND RIDGES}

Ice stream $A$ is different from ice streams B and C in its subglacial physiography (Shabtaie and others in press[b]). It lies against the wall of the Transantarctic Mountains on one side, and also shows a more pronounced subglacial margin on its other side than the other ice streams do. However, its surface looks very much like that of ice stream B, characterized by a ridge/trough structure parallel to ice movement with an amplitude of some $20 \mathrm{~m}$ (Fig.5). As on ice stream $B$, the surface slope diminishes downstream and out on to the "ice plain", but in contrast to ice stream $B$ the slope continues to diminish right to the grounding line. There is nothing in the surface appearance of ice stream A that suggests that it is fundamentally different in dynamics from ice stream B.

Ridge $A B$ is characterized by an irregular surface topography also (Shabtaie and others in press[b]). One might expect on a simple sheet-flow dome or ridge that the surface contours would be smooth, indicating a simple pattern of outflow. Instead, the surface topography is characterized by a complex pattern of valleys and ridges (Fig.5), which suggests that simple equilibrium does not exist here. Ridge BC shows two domes (the larger around grid position $5.4^{\circ} \mathrm{S}, 4.6^{\circ} \mathrm{W}$, and the smaller at grid $5.9^{\circ} \mathrm{S}$, $\left.2.7^{\circ} \mathrm{W}\right)$ separated by a transverse valley. Surface slopes are smooth downstream of the larger dome, which suggests to us an equilibrium form. Farther up-stream, however, the surface again is very irregular, perhaps reflecting a complex transient interaction with the upper parts of ice streams B and C. Siple ice dome, grid south of ice stream C, displays a regular, although asymmetric, dome-like shape.

\section{ROSS ICE SHELF}

Radar profiling has helped to delineate several features of the Ross Ice Shelf. Ice rises are of particular interest. Since an ice rise, by definition, is characterized by ice movement that is largely independent of the surrounding ice shelf and carries only the local accumulation in a largely radial outflow, longitudinal stresses are small and there are 


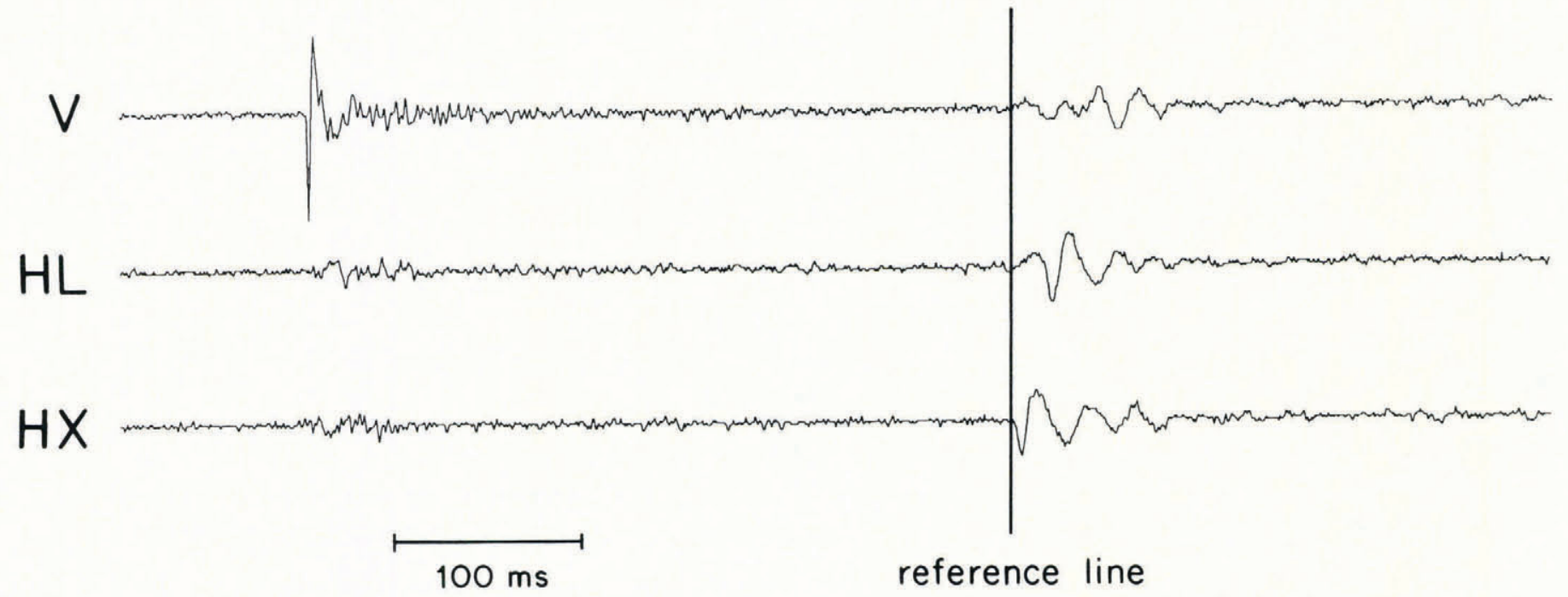

Fig.8. Passive seismogram of an event at the base of the ice stream near the recording array. The first trace (V) records vertical motion, the second (HL) horizontal motion along the axis of the ice stream, and the third (HX) horizontal motion normal to that axis. Note the close similarity between the wave forms on the HL and HV axes, and the $16 \mathrm{~ms}$ delay between the two traces.

no surface crevasses. Consequently, radar echoes from the surface of an ice rise exhibit little clutter; this characteristic can be used for mapping. On this basis Crary Ice Rise was found by Shabtaie and Bentley (in press) to extend about $70 \mathrm{~km}$ farther to the grid northwest than previously mapped, and to be flanked by two narrow, clutter-free strips with ill-defined boundaries on each side (Fig.3) that may also be ice rises.

Upstream from Crary Ice Rise there is another small area that shows a clutter-free zone on the radar record "ice rise a" (Fig.3: grid position $5.3^{\circ} \mathrm{S}, 2.1^{\circ} \mathrm{W}$ ). Although there are no boundary crevasses visible, either from the air or from the surface, the radar clutter is strong at the boundary, suggesting the presence of buried crevasses. Shabtaie and Bentley (in press) show "ice rise a" right on the suture zone that continues down-stream along the axis of ice stream B from the point of "ridge B1/B2" (Fig.3). Recent measurements by Bindschadler and others (in press) show that "ice rise a" is moving at the same speed as the surrounding ice. Following an idea of Whillans and others (in press), we suggest that "ice rise a" is a piece of undisturbed ice that broke off the point of "ridge B1/B2" and was carried on down the ice stream more or less undeformed. It should be noted that "ice rise a" still lies up-stream of the grounding line, within the "ice plain". Because it is moving, "ice rise a" is not really an ice rise at all, nor is it an ice rumple, because the surrounding ice is grounded. We propose the term "glacial microplate" for such a feature, i.e. an "island" of undisturbed ice moving within an ice stream or "ice plain". It is possible that the clutterfree strips that flank Crary Ice Rise are "glacial microplates", and even that the up-stream end of Crary Ice Rise itself incorporates "glacial micro-terranes".

The strong boundary crevasse zones of the ice stream mark flow bands that can be followed far out on to the Ross Ice Shelf (Shabtaie and Bentley in press). Knowledge of the boundaries of the ice streams and their flow bands make it possible to calculate the ice discharge from each ice stream draining into the Ross Ice Shelf. Fluxes out of ice streams B and C have each been measured in two places. On ice stream B one line is at the head of the "ice plain" and the other near the grounding line. On the flow band from ice stream $\mathrm{C}$, the up-stream gate is at the grounding line and the down-stream gate is about $200 \mathrm{~km}$ farther down-stream on the ice shelf. For neither of these pairs of gates is there a significant difference between influx and outflux (Shabtaie and Bentley, in press). Shabtaie and Bentley (in press) also compare the outflow from all the "Ross ice streams" to an estimate of input through snow accumulation on the whole interior of the West Antarctic ice sheet up to the ice divide. They find for the entire system a net balance that is suggestively, but not conclusively (in terms of the errors in measurement), negative by about $10-20 \mathrm{~km}^{3} \mathrm{a}^{-1}$.

The ice flux into the Ross Ice Shelf from the West Antarctic inland ice can be compared with the output through a line about $100 \mathrm{~km}$ inland of the front of the ice shelf (Bentley 1985). If one assumes that the Ross Ice Shelf itself is in balance, that leads to an estimate for the average bottom melt rate of $0.11 \pm 0.03 \mathrm{~m} \mathrm{a}^{-1}$ for the part of the ice shelf that lies inland of the output line. For the whole ice shelf, the estimated total volume loss by melting on the assumption of steady state is $60 \pm 15 \mathrm{~km}^{3} \mathrm{a}^{-1}$. This is about half the estimate that one gets from the oceanographic measurements of Pillsbury and Jacobs (1985), which give $150 \pm 75 \mathrm{~km}^{3} \mathrm{a}^{-1}$, after correction for the melt $\left(30 \mathrm{~km}^{3} \mathrm{a}^{-1}\right)$ in the high melt-rate region seaward of the output line (extrapolated from Giovinetto and Zumberge (1968)). In view of the quoted errors and the fact that the calculation by Giovinetto and Zumberge (1968) was based on only one line of measurements, these estimates of melt rate cannot be considered significantly different.

\section{ACKNOWLEDGEMENTS}

This work was supported by the National Science Foundation under grant DPP-8412404. This is contribution number 461 of the Geophysical and Polar Research Center, University of Wisconsin-Madison.

\section{REFERENCES}

Alley R B, Blankenship D D, Bentley C R, Rooney S T 1986 Deformation of till beneath Ice Stream B, West Antarctica. Nature 322 (6074): 57-59

Alley R B, Blankenship D D, Bentley C R, Rooney S T In press[a] Till beneath Ice Stream B. 3. Till deformation: evidence and implications. Journal of Geophysical Research

Alley R B, Blankenship D D, Rooney S T, Bentley C R In press[b] Till beneath Ice Stream B. 4. A coupled ice-till flow model. Journal of Geophysical Research

Bentley C R 1971 Seismic anisotropy in the West Antarctic ice sheet. In Crary A P (ed) Antarctic snow and ice studies. II. Washington, DC, American Geophysical Union: 131-177 (Antarctic Research Series 16) 
Bentley C R 1972 Seismic-wave velocities in anisotropic ice: a comparison of measured and calculated values in and around the deep drill hole at Byrd Station, Antarctica. Journal of Geophysical Research 77(23): 4406-4420

Bentley C R 1985 Glaciological evidence: the Ross Sea sector. In Glaciers, Ice Sheets, and Sea Level: Effect of a $\mathrm{CO}_{2}$-induced Climatic Change. Report of a workshop held in Seattle, Washington, September 13-15, 1984. Washington, DC, U.S. Department of Energy: 178-196

Bentley C $R$ In press Antarctic ice streams: a review. Journal of Geophysical Research

Bindschadler $R$ A, Stephenson $S \mathrm{~N}$, MacAyeal D R, Shabtaie S In press[a] Ice dynamics at the mouth of Ice Stream B, Antarctica. Journal of Geophysical Research

Bindschadler R A, MacAyeal D R, Stephenson S N In press[b] Ice stream-ice shelf interaction in West Antarctica. In Proceedings of Utrecht Workshop on the Dynamics of the West Antarctic Ice Sheet. Dordrecht, D. Reidel

Bindschadler R A, Stephenson S N, MacAyeal D R, Shabtaie $S$ In press[c] Interaction between Ice Stream B and Ross Ice Shelf, Antarctica. Antarctic Journal of the United States

Blankenship D D Unpublished P-wave anisotropy in the high polar ice of East Antarctica. (Master's thesis, University of Wisconsin, Madison, 1982)

Blankenship D D, Bentley C R, Rooney S T, Alley R B 1986 Seismic measurements reveal a saturated porous layer beneath an active Antarctic ice stream. Nature 322 (6074):54-57

Blankenship D D, Anandakrishnan S, Kempf J L, Bentley C R 1987 Microearthquakes under and alongside ice stream B, Antarctica, detected by a new passive seismic array. Annals of Glaciology 9: 30-34

Blankenship D D, Bentley C R, Rooney S T, Alley R B In press Till beneath Ice Stream B. 1. Properties derived from seismic travel times. Journal of Geophysical Research

Giovinetto M B, Zumberge J H 1968 The ice regime of the eastern part of the Ross Ice Shelf drainage system. International Association of Scientific Hydrology Publication 79 (General Assembly of Bern 1967 - Snow and Ice): $255-266$

Gow A J 1970 Preliminary results of studies of ice cores from the $2164 \mathrm{~m}$ deep drill hole, Byrd Station, Antarctica. International Association of Scientific Hydrology Publication 86 (ISAGE): 78-90

Gravenor C P, Meneley W A 1958 Glacial flutings in central and northern Alberta. American Journal of Science 256(10): $715-728$

Hughes T 1975 The West Antarctic ice sheet: instability, disintegration, and initiation of ice ages. Reviews of Geophysics and Space Physics 13(4): 502-526

Kohnen H, Gow A J 1979 Ultrasonic velocity investigations of crystal anisotropy in deep ice cores from Antarctica. Journal of Geophysical Research 84(C8): 4865-4874

Pillsbury R D, Jacobs S S 1985 Preliminary observations from long-term current meter moorings near the Ross Ice Shelf, Antarctica. In Jacobs S S (ed) Oceanology of the Antarctic continental shelf. Washington, DC, American Geophysical Union: 87-107 (Antarctic Research Series 43)

Poulter T C 1950 Geophysical studies in the Antarctic. Stanford, CA, Stanford Research Institute

Robertson J D Unpublished Geophysical studies on the Ross Ice Shelf, Antarctica. ( $\mathrm{PhD}$ thesis, University of Wisconsin, Madison, 1975)

Robertson J D, Bentley C R In press Seismic studies on the grid - western Ross Ice Shelf. Washington, DC, American Geophysical Union (Antarctic Research Series)

Robin G de Q, Weertman J 1973 Cyclic surging of glaciers. Journal of Glaciology 12(64): 3-18

Robin G de Q, Swithinbank C W M, Smith B M E 1970[a] Radio echo exploration of the Antarctic ice sheet. International Association of Scientific Hydrology Publication 86 (ISAGE): 97-115

Robin G de Q, Evans S, Drewry D J, Harrison C H, Petrie D L 1970[b] Radio-echo sounding of the Antarctic ice sheet. Antarctic Journal of the United States 5(6): 229-232
Rooney S T, Blankenship D D, Alley R B, Bentley C R In press Till beneath Ice Stream B. 2. Structure and continuity. Journal of Geophysical Research

Rose K E 1979 Characteristics of ice flow in Marie Byrd Land, Antarctica. Journal of Glaciology 24(90): 63-75

Schultz D G, Powell L A, Bentley C R 1987 A digital radar system for echo studies on ice sheets. Annals of Glaciology 9: 206-210

Shabtaie S, Bentley C R 1986 Ice streams and grounding zones of West Antarctica and the Ross Ice Shelf. (Abstract.) Annals of Glaciology 8: 199-200

Shabtaie S, Bentley C R In press West Antarctic ice streams draining into the Ross Ice Shelf: configuration and mass balance. Journal of Geophysical Research

Shabtaie S, Bentley C R, Whillans I M, MacAyeal D R, Bindschadler R A In press[a] Partial collapse of the West Antarctic ice sheet: implications from mass balance studies of ice streams. Journal of Geophysical Research

Shabtaie S, Whillans I M, Bentley C R In press[b] Surface elevations on ice streams A, B, and C. Journal of Geophysical Research

Thomas R H, MacAyeal D R, Eiler D H, Gaylord D R 1984 Glaciological studies on the Ross Ice Shelf, Antarctica, 1973-1978. In Bentley C R, Hayes D E (eds) The Ross Ice Shelf: glaciology and geophysics. Washington, DC, American Geophysical Union: 21-53 (Antarctic Research Series 42)

Whillans I M, Bolzan J, Shabtaie S In press Velocity of Ice Stream B, Antarctica, and its mass balance. Journal of Geophysical Research 